УДК 373.211 .24

(C) Тарарак Н. Г., 2021 p.

http://orcid.org/0000-0001-5350-8594

DOI 10.34142/23128046.2021.51.14

Н. Г. Тарарак

\title{
ФОРМИ СТИМУЛЮВАННЯ ВИХОВАТЕЛІВ ЗАКЛАДІВ ДОШКІЛЬНОЇ ОСВІТИ (ДРУГА ПОЛОВИНА ХХ СТ.)
}

У статті проаналізовано провідні форми стимулювання вихователів закладів дошкільної освіти до професійного зростання, які набули свого широкого використання в другій половині $X X$ століття. 3'ясовано, щчо до розповсюджених форм заохочення дошкільних прачівників у досліджуваний період належали: друк статей, що були присвячені діяльності найкращих вихователів; нагородження їх високими урядовими нагородами, наприклад, медаллю «За трудову відзнаку»; організачія різноманітних курсів, семінарів, науково-практичних конференцій, «кущових об’єднань»; проведення педагогічних читань, нарад дошкільних працівників; активний рух за оволодіння вихователями педагогічною майстерністю, котрий було присвячено ювілейним подіям; вивчення діяльності дитячих садків, колективні перегляди, постійні спостереження зароботою вихователів - майстрів своєї справи; взаємовідвідування закладів дошкільної освіти, надання їм взаємодопомоги; організаиія шефської допомоги досвідчених фахівиів молодим спеціалістам; надання різнопланових завдань $і$ доручень, проведення виставок, перевірка $i$ взаємоперевірка, організація обміну досвідом та підведення підсумків на розширених педагогічних нарадах; проведення показових відкритих занять, котрі дозволяли присутнім проаналізувати побачене, висловити власну думку, відзначити, що доцільно запозичити, домовитися щодо термінів упровадження кращого досвіду у власну практичну діяльність. На указаних заходах широко обговорювалися питання стосовно покращення якості виховання дітей дошкільного віку, необхідності масового розповсюдження й упровадження в практику ЗДО передового педагогічного досвіду.

Особливу увагу приділено Республіканським педагогічним читанням як дієвій формі заохочення дошкільних працівників до професійного зростання. Учасники отримували матеріальні премії, иінні подарунки, путівки, почесні грамоти, листи подяки тощо. 3 метою заохочення прачівників дошкільного профілю до самовдосконалення, кращим серед них було вручено значок «Відмінник народної освіти УРСР». Установлено, щзо саме в другій половині ХХ століття активно порушувалось питання щодо необхідності урізноманітнення форм матеріального, морального ц̆ професійного стимулювання та упровадження в практику діяльності закладів дошкільної освіти краших досягнень педагогічної науки. 
Ключові слова: стимулювання, заклад дошкільної освіти, вихователь, професійна діяльність, матеріальні та моральні заохочення.

Tararak N. H. Forms of encouragement of teachers of preschool education institutions (the second half of the $\mathbf{X X}^{\text {th }}$ century). The article analyzes the leading forms of encouragement of teachers of preschool education institutions to the professional growth which became widely used in the second half of the XX ${ }^{\text {th }}$ century. It has been found that the common forms of encouragement of preschool workers in the study period included printing articles on the activities of the best teachers; rewarding them with high government rewards such as Medal for Merit; organization of various courses, seminars, scientific and practical conferences, clusters; conducting pedagogical readings, meetings of preschool workers; an active movement for the mastery of pedagogical skills by teachers which was dedicated to the anniversary events; studying the activities of kindergartens, constant monitoring of the work of preschool teachers - real artists; mutual visits of preschool education institutions, providing them with mutual assistance; organization of patronage of experienced specialists to young ones; providing various tasks and assignments, holding exhibitions, checking and cross-checking, organizing the exchange of experience and summarizing the results of extended pedagogical meetings; conducting demonstration classes which allowed the participants to analyze what they had seen, to express their own opinion, to note what was advisable to borrow, to agree on the timing of the introduction of the best ideas in their work. At these events, issues related to improving the quality of education of preschool children, the need for mass dissemination and implementation of advanced pedagogical experience in the practice of IPE were widely discussed.

Particular attention is paid to the Republican pedagogical readings as an effective form of encouraging preschool workers to the professional growth. Participants got material awards, valuable gifts, vouchers, diplomas, letters of thanks and more. In order to encourage preschool workers to self-improvement, the best among them were rewarded the badge "Excellence in Public Education of the USSR." It has been established that in the second half of the XX $X^{\text {th }}$ century the question of the need to diversify the forms of material, moral and professional encouragement and the introduction of the best achievements of pedagogy in the practice of preschool education institutions was actively raised.

Keywords: encouragement, preschool institution, preschool teacher, professional activity, material and moral encouragement.

Вступ. Одним із пріоритетних завдань розвитку освіти в сучасній Україні визначено прояв самоактивності особистості в досягненні найвищого рівня педагогічної майстерності, креативності, професіоналізму, що актуалізує проблему стимулювання вихователів закладів дошкільної освіти (ЗДО) до професійного зростання. 
Установлено, що окремі питання готовності фахівців до професійного вдосконалення й шляхи їх формування вивчали М. Костенко, Л. Притуляк, Т. Тихонова, П. Харченко. Питанням самоактуалізації, мотивації й самореалізації особистості присвятили свої праці Г. Аксьонова, Г. Балл, Ю. Долинська, М. Лазарєв, О. Пєхота, Н. Сегеда та ін.

Проте, незважаючи на різноманітність і багатоаспектність висвітлення науковцями проблеми підготовки майбутніх фахівців до різних форм професійного зростання, недостатньо вивченими залишаються питання форм стимулювання дошкільних працівників до професійної діяльності.

Мета та завдання. Мета статті полягає в аналізі форм стимулювання вихователів закладів дошкільної освіти до професійного зростання в другій половині XX століття.

Методи дослідження. Після визначення теми й мети статті було використано такі методи наукового пізнання, як: а) аналіз, синтез, порівняння, узагальнення - для з'ясування дієвих форм стимулювання дошкільних працівників до професійного вдосконалення; б) хронологічний, порівняльнозіставний - для інтерпретації результатів наукового пошуку в обраних хронологічних межах.

Результати. Вивчення та узагальнення науково-педагогічних джерел i періодичних видань окресленого етапу дозволяє констатувати, що урядова політика того часу сприяла стимулюванню вихователів закладів дошкільної освіти до професійного зростання.

Наприклад, до розповсюджених форм заохочення в другій половині XX століття належали: видання статей, котрі були присвячені найкращим вихователям, нагородження їх високими урядовими нагородами, зокрема, медаллю «За трудову відзнаку» (Holubivska, 1971). Такі форми стимулювання були спрямовані на досягнення дошкільними працівниками високих результатів у своїй професійній діяльності, подальше просування в ній, досягнення як успішного функціонування, так і творчої самореалізації вихователів закладів дошкільної освіти. Взагалі, високі нагороди в України отримали 109 керівників закладами дошкільної освіти, вихователів, методистів й інших дошкільних працівників (Holubivska, 1971).

Як свідчить проведене дослідження, стимулюванню дошкільних працівників до підвищення свого професійного рівня сприяло і прийняття урядових документів. Так, українським урядом були затверджені такі положення, як «Положення про дитячі дошкільні заклади у колгоспах Української РСР» (1966 рік) та «Положення про об’єднану дошкільну дитячу установу (ясла-сад)» (1960 рік). Також в досліджуваний період було введено новий тип ЗДО - ясла-садок, який був своєрідним стимулом до зростання 
професійного рівня дошкільних працівників, так як догляд за дітьми різного віку вимагав від вихователів знань щодо особливостей поводження 3 ними. У зазначених документах також були визначені i найбільш дієві форми стимулювання до професійного зростання сільських вихователів. Це: заочне навчання в профільних 3ВО; допомога у виданні різноманітних методичних рекомендацій, грошова допомога кращим вихователям закладів дошкільної освіти тощо.

До ефективних форм стимулювання дошкільних працівників до професійного зростання в окреслений період також належали: організація різноманітних курсів, семінарів, науково-практичних конференцій, проведення педагогічних читань, нарад дошкільних працівників. На цих заходах активно обговорювалися питання щодо покращення якості виховання дітей, необхідності широкого розповсюдження i впровадження в практику ЗДО передового педагогічного досвіду (Uliukaieva, 1993).

Узагальнення науково-педагогічних даних, дозволяє стверджувати, що однією із поширених форм заохочення вихователів ЗДО до професійного зростання був активний рух за оволодіння вихователями педагогічною майстерністю, котрий було присвячено 50-річчю Жовтневої революції. Також 3'ясовано, що достатньо дієвим у другій половині XX століття було заохочення дошкільних працівників до роботи в «кущових об'єднаннях» (Kushchovi obiednannia, 1966).

Варто наголосити на тому, що до так званого «куща» входили 4-5 дитячих садків, котрі було об’єднано територіально. Функції керівника виконувала завідувачка кращого дитячого садка. Вихователі об'єднаних дитячих садків разом визначали конкретні форми роботи, план дій, терміни його виконання, розподіляли між собою основні обов'язки.

Велика роль у реалізації питань стимулювання дошкільних працівників до професійного зростання, виборі провідних форм заохочення належала керівникам кущових об’єднань і їхнім помічникам. Саме вони впроваджували в заклад дошкільної освіти таку форму професійного зростання вихователів ЗДО, як направлення їх на різноманітні проблемні конференції, допомога у визначенні теми доповіді, окреслення можливих шляхів реалізації проблемного питання та ін.

До педагогічно цінних форм стимулювання вихователів закладів дошкільної освіти, як свідчать науково-педагогічні джерела, у досліджуваний період належало і проведення показових відкритих занять, котрі дозволяли присутнім проаналізувати побачене, висловити власну думку, відзначити, що доцільно запозичити, домовитися щодо термінів упровадження кращого досвіду у власну практичну діяльність. 
Таким вихователям та керівник закладів дошкільної освіти, які не мали належного досвіду роботи у «кущових об’єднаннях», приділялась особлива увага. Зокрема, з метою надання систематичної допомоги до них прикріпляли педагога-вихователя 3 великим досвідом роботи. Після проходження встановленого терміну і для визначення результатів професійного зростання дошкільних працівників використовувався такий метод заохочення, як взаємоперевірка, котрий полягав у тому, що колектив одного закладу дошкільної освіти під керівництво завідувача перевіряв роботу іншого. Після чого всі учасники такого об'єднання збиралися в одному із закладів дошкільної освіти, прослуховували повідомлення вихователів і завідувачів, оцінювали діяльність, обмінювалися думками, звертали увагу на досягнення і недоліки, підводили підсумки.

Iз представленого кущовими об'єднаннями досвіду вихователів та керівників закладів дошкільної освіти обирався матеріал для обговорення на районних методичних об'єднаннях.

На основі звітів методичних об'єднань було з'ясовано, що питаннями планування роботи методичних кабінетів займалися методисти району, які постійно здійснювали контроль діяльності кущових об'єднань, надавали, якщо була в цьому потреба, допомогу на місцях, відвідували об'єднані педагогічні наради, перевіряли підготовку вихователів дитячих садків, вивчали питання поширення та впровадження передового педагогічного досвіду, процес професійного зростання дошкільних працівників, надавали консультації щодо тематики і змісту доповідей та повідомлень.

Установлено, що чим більш різноманітними були форми роботи кущових об'єднань, чим більше вони були приведені до відповідності потребам кожного закладу дитячої освіти і заохоченню кожного із дошкільних працівників до професійного зростання, тим більш значущими були результати, а саме: суттєво збільшено кількість закладів із чітко організованою педагогічною діяльністю, здійснено відзначення кращих вихователів та працівників закладів дошкільної освіти тощо.

Таким чином, такі форми професійного зростання вихователів закладів дошкільної освіти, як: вивчення діяльності дитячих садків, колективні перегляди, постійні спостереження за роботою вихователів - майстрів своєї справи, взаємовідвідування закладів дошкільної освіти, надання їм взаємодопомоги, організація шефської допомоги досвідчених фахівців молодим спеціалістам, надання різнопланових завдань і доручень, проведення виставок, перевірка i взаємоперевірка, організація обміну досвідом та підведення підсумків на розширених педагогічних нарадах, безумовно, мали позитивні наслідки i 
сприяли стимулюванню вихователів закладів дошкільної освіти до професійного зростання.

Необхідно наголосити на тому, що поширеною в досліджуваний період залишалася i така форма стимулювання, як нагородження дошкільних працівників почесними грамотами, відзнаками, медалями, значками тощо.

Зокрема, у 1967 році було затверджено Почесну грамоту Міністерства освіти СРСР і ЦК профспілок працівників освіти, вищої школи і наукових установ.

У січні 1970 року в м. Києві у зв’язку зі 100-річчям від дня народження B.I. Леніна були проведені республіканські педагогічні читання, на яких було порушено питання щодо форм та методів стимулювання педагогічних працівників до професійного зростання. Це: підвищення статусу професії вихователя в суспільстві; збільшення заробітної плати педагогічних працівників відповідно до рівня їхньої кваліфікації; надання пільгових путівок для відпочинку в санаторіях, будинках відпочинку, дитячих таборах; відзначення кращих працівників закладів дошкільної освіти на Дошці пошани; презентація їх досягнень у професійних журналах та газетах; присудження державних нагород тощо.

Як свідчить науково-педагогічна література, до ефективних форм стимулювання дошкільних працівників у 70-80-ті pp. ХХ століття належали Всесоюзні та Республіканські огляди діяльності закладів дошкільної освіти.

Перші такі огляди в Україні почали проводитися в 1970 - 1971 рр. Переможці отримували матеріальні премії, цінні подарунки, путівки, почесні грамоти, листи подяки та ін.

Аналіз науково-педагогічних джерел свідчить, що в 70-х рp. ХХ століття в м. Харків пройшли обласні педагогічні читання, котрі також були присвячені ювілею В. І. Леніна. 3 метою стимулювання працівників дошкільного профілю до самовдосконалення, кращим серед них було вручено значок «Відмінник народної освіти УРСР», грамоти та премії.

Працівники закладів дошкільної освіти постійно вдосконалювали свою педагогічну майстерність. 3 цією метою вони брали активну участь у семінарах, котрі були присвячені питанням дошкільного виховання, зустрічалися 3 молодими вихователями, передавали їм свій багатий досвід (Pro osvitu, 1996).

17 березня 1973 року було прийнято Постанову Ради Міністрів СРСР «Про заходи подальшого розвитку мережі дитячих дошкільних закладів у колгоспах». У відповідності до зазначеної Постанови було передбачено упровадження певних форм матеріального заохочення, які сприяли покращенню соціального забезпечення педагогічного та медичного персоналу закладів дошкільної освіти, порушувалось питання щодо необхідності урізноманітнення форм 
матеріального, морального й професійного стимулювання та упровадження в практику діяльності закладів дошкільної освіти кращих досягнень педагогічної науки та передового педагогічного досвіду.

Вивчення та узагальнення науково-педагогічних матеріалів дозволяє констатувати, що в 70-ті pp. ХХ століття в Україні було активізовано науководослідницьку роботу 3 дошкільної педагогіки, яка проводилась відділом дошкільного виховання (Науково-дослідний інститут педагогіки УРСР) та психологї дітей дошкільного віку (Науково-дослідний інститут психології УРСР), а також викладачами кафедр дошкільної педагогіки (Київський, Запорізький, Рівненський та Слов’янський педагогічний інститут) (Hrynchenko, 1906).

Саме в цей період працівники закладів дошкільної освіти залучались до виступів на нарадах, брали активну участь у педагогічних читання, конференціях, семінарах із різних питань дошкільного виховання, 3 задоволенням зустрічалися з молодими вихователями, охоче передавали їм свій багатолітній досвід.

Варто також наголосити на особливому значенні Республіканських педагогічних читань як дієвих форм заохочення дошкільних працівників до самовдосконалення.

Як свідчить проведене дослідження, в 70 - 80-ті рр. ХХ століття однією 3 поширених форм стимулювання вихователів закладів дошкільної освіти до професійного самовдосконалення були Виставки досягнень народного господарства СРСР. Наприклад, дитячий заклад № 23 м. Києва (1975 р.) став учасником такої виставки й отримав Диплом пошани та золоту медаль ВДНГ CPCP (Pedahoh pishov na pensiiu, 1966).

Самовдосконаленню дошкільних працівників сприяло i проведення Всесоюзної науково-практичної конференції «Діяльність дошкільних закладів і органів народної освіти щодо підвищення педагогічної культури батьків» (м. Дніпропетровськ, 1980 р.). Учасники конференції були ознайомлені 3 цікавими та різноманітними формами роботи вихователів із батьками, які набули визнання на Дніпропетровщині (Venzhyk, 1980).

Таким чином, провідну роль щодо стимулювання вихователів закладів дошкільної освіти до професійного самовдосконалення та поширення педагогічно цінного досвіду відігравали виставки досягнень народного господарства СРСР та УРСР. Зокрема, в 1980 - 1984 рр. досягнення українських фахівців у галузі дошкільної освіти були оцінені 3 золотими, 6 срібними, 29 бронзовими медалями й 15 дипломами. Наприклад, золоті медалі та дипломи I ступеня отримали: заклад дошкільної освіти № 50 (м. Одеса), ясла-садок № 90 (м. Сімферополь) і Уманський райвно Черкаської області. 
Сотні вихователів були нагороджені почесними грамотами за «Успіхи в роботі», «Змістовну освітню виховну роботу», керівники закладів дошкільної освіти - грамотами «Вмілий організатор». Саме в 80-ті pp. ХX століття починають присвоювати почесні звання. Зокрема, звання заслуженого вчителя УРСР одержала керівниця зразкового закладу дошкільної освіти № 221 м. Києва О. І. Піскунова.

Як свідчить проведене дослідження, до поширених форм самовдосконалення вихователів закладів дошкільної освіти в 80-ті pp. XX століття належала така форма як проведення сумісних семінарів вихователів дошкільних установ і вчителів підготовчих класів до школи. Така форма дозволяла вихователям і вчителям обмінюватися досвідом роботи, відвідувати уроки і заняття в закладі дошкільної освіти, а потім аналізувати побачене, що сприяло їхньому самовдосконаленню.

Як уже наголошувалося, провідна роль щодо стимулювання вихователів закладів дошкільної освіти до професійного самовдосконалення відводилась педагогам-наставникам, які повинні навчати молодих вихователів правильним прийомам впливу на дошкільнят, допомагати їм підвищувати свій політичний та загальноосвітній рівень, оволодівати методикою організації освітнього процесу.

Також уважаємо доречним 3'ясувати роль і значення профспілкових комітетів закладів дошкільної освіти в реалізації питань стимулювання вихователів до професійного зростання.

Профспілкові комітети правомірно вбачали вирішальну роль заохочень щодо успішного виконання педагогічним колективом закладу дошкільної освіти завдань, висунутих урядом. До провідних форм стимулювання дошкільних працівників профспілки відносили переважно грошові нагороди.

Обговорення. Проведене дослідження підтверджує висновки науковців про те, що в другій половині XX століття були чітко визначені провідні форми стимулювання вихователів закладів дошкільної освіти до професійного зростання. Установлено, що реалізацією питань заохочення дошкільних працівників у досліджуваний період займалися як відповідні міністерства, так і профспілкові комітети.

Висновки. Підводячи підсумки, варто звернути увагу на те, що в Україні в період, який вивчається, нараховувалась велика кількість педагогів, досвід яких широко вивчався i використовувався. До провідних форм стимулювання вихователів закладів дошкільної освіти належали: відзнака високими урядовими нагородами, вручення почесних грамот Міністерства освіти УРСР, значків «Відмінник народної освіти», медалей «За трудову відзнаку», дипломів виставок досягнень народного господарства СРСР та УСРС, організація курсів, Всесоюзних та Республіканських оглядів діяльності закладів дошкільної освіти, 
проведення семінарів, науково-практичних конференцій, педагогічних читань, нарад дошкільних працівників, проведення показових відкритих занять, спільних семінарів вихователів закладів дошкільної освіти та вчителів підготовчих до школи класів, участь вихователів у кущових об’єднаннях та деякі інші.

\section{ЛІТЕРАТУРА:}

Венжик Л. 3 найвищою віддачею [Текст]. Дошкільне виховання. 1980. № 9. С. 1-2.

Голубівська Г. Ю. Їх удостоєно високих нагород [Текст]. Дошкільне виховання. 1971. № 11. C. $17-18$.

Гринченко Б. Д. Народні вчителі і українська школа [Текст]. К. : Б.в., 1906. 89 с.

Кущові об'єднання [Текст]. Дошкільне виховання. 1966. № 12. С. 18-19.

Педагог пішов на пенсію [Текст]. Доикільне виховання. 1966. № 10. С. 43-45.

Про освіту [Текст] : закон України. Освіта. 1996. № 43-44. С. 6-11.

Улюкаєва І. Г. Стан дослідження історії становлення і розвитку суспільного дошкільного виховання в історико-педагогічній науці [Текст] : дис. ... канд. пед. наук : 13.00.01/ І. Г. Улюкаєва. - К., 1993. - 190 с.

\section{REFERENCES:}

Holubivska, H. Yu. (1971). Yikh udostoieno vysokykh nahorod [Tekst]. [Awarded with them high rewards]. Doshkilne vykhovannia. № 11. S. 17-18. (in Ukranian).

Hrynchenko, B. D. (1906). Narodni vchyteli i ukrainska shkola. [People's Teachers and Ukrainian School]. [Tekst]. K. : B.v. 89 s. (in Ukranian).

Kushchovi obiednannia (1966). [Bush combining]. [Tekst]. Doshkilne vykhovannia. № 12. S. 18-19 (in Ukranian).

Pedahoh pishov na pensiiu (1966). [Pedagog has retired]. [Tekst]. Doshkilne vykhovannia. № 10. S. 43-45 (in Ukranian).

Pro osvitu (1996). [About education]. [Tekst] : zakon Ukrainy. Osvita. № 43-44. S. 6-11. (in Ukranian).

Uliukaieva, I. H. (1993). Stan doslidzhennia istorii stanovlennia i rozvytku suspilnoho doshkilnoho vykhovannia $\mathrm{v}$ istoryko-pedahohichnii nautsi [The state of studying the history of formation and development of social preschool education in historical and pedagogical science]. [Tekst] : dys. ... kand. ped. nauk : 13.00.01. K., 190 s. (in Ukranian).

Venzhyk, L. (1980). Z naivyshchoiu viddacheiu. [With the greatest return]. [Tekst] Doshkilne vykhovannia. № 9. S. 1-2. (in Ukranian).

\begin{tabular}{l}
\hline \multicolumn{2}{c}{ Інформація про автора: } \\
Тарарак Наталія Григорівна: \\
ORCID: https://orcid.org/0000-0001-5350- \\
8594, доктор педагогічних наук, професор, \\
завідувач кафедри теорії, технологій i \\
методик дошкільної освіти, Харківський \\
національний педагогічний університет \\
імені Г. С. Сковороди, вул. Валентинівська, \\
2, м. Харків, Україна 61166 \\
e-mail: dochfak_hnpu@ @mail.com
\end{tabular}

Information about the author: Tararak NatalIya Hryhorivna:

ORCID: https://orcid.org/0000-0001-5350-

8594, Doctor of pedagogical sciences,

Professor, Head of the Department of Theory,

Technologies and Methods of Preschool

Education, H. S. Skovoroda Kharkiv National

Pedagogical University, Valentynivska street,

2, Kharkiv, Ukraine 61166

e-mail: dochfak_hnpu@gmail.com 
Цитуйте цю статтю як: Тарарак Н. Г. Форми стимулювання вихователів закладів дошкільної освіти (друга половина XX ст.). Теорія та методика навчання та виховання. 2021. № 51. C. $146-155$.

DOI: $10.34142 / 23128046.2021 .51 .14$

Дата надходження статті до редакції: 20.10.2021

Стаття прийнята до друку: 03.11.2021 